\title{
Using Biferon-B for the prevention of mastitis in cows
}

\author{
Sergey Shabunin, Alexander Pashentsev, Nikolay Klimov*, Valentina Morgunova, and Vasilina Gritsyuk \\ All-Russian Veterinary Research Institute of Pathology, Pharmacology and Therapy, 394087 Voronezh, Russia
}

\begin{abstract}
The developed method for the prevention of mastitis in lactating cows by intramuscular injection of Biferon-B at doses of 5.0-10.0-20.0 ml, provided a preventive effect in 25.0-75.0\% of animals; the best effect was achieved with Biferon-B at a dose of $5.0 \mathrm{ml}$. The use of Biferon-B in clinically healthy lactating animals was accompanied by a decrease in blood levels of stab neutrophils by 58.8-65.0\%, circulating immune complexes by 23.4-62.6\%, with a higher content of segmented neutrophils by $4.8-7.8 \%$, monocytes by $5.6-57.1 \%$, lymphocytes by $4.9-12.3 \%$, total immunoglobulins by $5.7-14.3 \%$, bactericidal and lysozyme activity of blood serum by $6.4-23.1 \%$ and $4.3-13.7 \%$, respectively. The phagocytic activity of neutrophils decreased by 5.6-10.9\%. With lower indicators of the intoxication index dropped by $12.8-19.1 \%$, the content of average molecular peptides by $2.4-22.6 \%$, nitric oxide by $24.5-45.4 \%$, MDA by $2.8-36.7 \%$; catalase activity increased by $2.7-12.8 \%$ and GPx by $10.4-29.7 \%$.
\end{abstract}

\section{Introduction}

The high incidence of mastitis in cows during all functional periods causes significant economic damage to dairy farming as a result of reduced milk productivity, milk quality, premature rejection, treatment costs, diseases of newborn calves [1,2].

In the occurrence and spread of inflammatory diseases of the mammary gland in cows, an important role is played by factors that reduce the resistance of the mammary gland and the body as a whole [3, 4].

Modern pharmaceuticals offer a wide range of veterinary drugs and methods for treating mastitis in cows. The main active ingredients of these drugs are antibiotics. However, their ubiquitous, and often unsystematic application led to a decrease in efficiency due to the development of resistant strains of microorganisms $[5,6]$.

Currently, an alternative to the use of an antimicrobial drug in the treatment and prevention of mastitis is the use of immunostimulating drugs, and in particular interferons obtained using recombinant protein technologies and having a wide spectrum of action due to activation of the immune system. Interferons act against many viruses and have antibacterial properties. The bacteriostatic effect is due to a significant violation of the bioenergetic processes in microorganisms due to the depletion of tryptophan, and the mediated bactericidal effect is due to the generation of nitric oxide and reactive oxygen species in macrophages [7-9]. The protective role of interferons in the body in bacterial infections is also associated with the activation of Tlymphocytes, macrophages, and natural killers that perform a protective function [10]. Taking into account the discovered and studied properties of interferons that indicate their participation in maintaining homeostasis, drugs with antiviral and immunomodulatory effects have been developed [11, 12].

Biferon-B, a drug exhibiting antiviral and immunostimulating activity, is a mixture of bovine recombinant $\alpha$ - and $\gamma$-interferons with species specificity and a total antiviral activity of at least $1.0 \times 10^{4} \mathrm{TCID} 50 / \mathrm{cm}^{3}$. According to its pharmacological properties, it affects the natural resistance (inducer of bactericidal and lysozyme activity) and immune status (induction of cellular and humoral immunity, endogenous cytokine system) in cattle. To date, two works are known in which data were obtained on the effect of bovine recombinant $\alpha$ - and $\gamma$-interferons (Biferon-B) on the nature of termination of pregnancy and the condition of cows and calves after birth [13] and the effectiveness of the combined use of bovine recombinant $\alpha$ - and $\gamma$-interferons and aminoseletone in subclinical mastitis in cows [14].

In this regard, the study of the influence of speciesspecific recombinant proteins on morphobiochemical, immunological status, microbiological and cytological indicators of the secretion of udder of cows is high on the agenda and requires detailed study.

\section{Materials and methods}

The studies involved 64 animals of black-and-white motley breed with milk productivity in the previous lactation of $6600-7100 \mathrm{~kg}$ of milk. The cows were managed tethered on a straw bedding. The groups were formed from the first day after calving. Cows were divided into four groups. On the first day after calving, the animals of the experimental group I $(n=16)$ were injected Biferon-B $5.0 \mathrm{ml}$ intramuscularly twice with an interval of 24 hours (Scientific-Production Center

Corresponding author: vetklimov@gmail.com 
"ProBioTech", Republic of Belarus). The animals from experimental group II $(\mathrm{n}=16)$ received $10.0 \mathrm{ml}$ each; those of the experimental group III $(n=16) 20.0 \mathrm{ml}$ each and in group IV (control, $\mathrm{n}=16$ ) the injections were not used. Biological material from animals was taken before and at the end of the experiment. Clinical observations of the animals were performed during 4 months. The state of the mammary gland was evaluated three times in a week according to the results of the study of milk with a quick mastitis test (2\% solution of Masttest). Morphological blood tests were performed on a ABX Micros 60 hematological analyzer with the definition of the leukocyte formula in accordance with the Guidelines for the Diagnosis, Treatment and Prevention of Metabolic Disorders in Productive Animals [15]. Immunological indicators, including serum bactericidal activity (SBA), and serum lysozyme activity (SLA) activity, total immunoglobulins (Ig), circulating immune complexes (CIC) in blood serum (humoral serum factors of natural non-specific resistance) and leukocyte phagocytic rate (LPR), phagocytic number (PN), phagocytic index (PI), the number of $\mathrm{T}$ - and $\mathrm{B}$ lymphocytes (cellular immunity), were determined using standard and unified methods in accordance with the Methodological Recommendations for Assessment and Correction of the Immune Status of Animals [16]. Bacteriological studies of the secretion of the udder, the study of the cultural-morphological and biochemical properties of the isolated microorganisms was carried out by generally accepted methods according to M.A. Sidorov, D.I., Skorodumov, V.B. Fedotov [17]. Statistical processing of the obtained data was carried out using Statistica 8.0 software (Stat-Soft Inc., USA).

\section{Results and discussion}

Background morphological, biochemical, immunological blood indices, bacteriological and cytological indices of the secretion of the change of animals of all groups of indices corresponded to optimal indices. We did not reveal significant differences between the groups.

The effectiveness of the use of Biferon-B is presented in Table 1. It was found that in the group of negative control for the four-month observation period, $50.0 \%$ (8 animals) fell ill, including $25.0 \%$ of subclinical ones (4 animals) and $25.0 \%$ of clinically expressed (4 animals). When prescribing Biferon-B in $5.0 \mathrm{ml}$, one animal fell ill with subclinical and clinically expressed catarrhal mastitis, which amounted to $12.5 \%$. The incidence of animals treated with Biferon-B at 10.0 $\mathrm{ml}$ was $25.0 \%$. In this group, 2 animals fell ill with subclinical and clinically expressed catarrhal mastitis.

Among animals to which a dose of $20.0 \mathrm{ml}$ BiferonB was applied, $37.5 \%$ of cows went through mastitis, including 2 cows with subclinical mastitis and 4 cows with clinically severe catarrhal mastitis.

Consequently, the monthly treatment of cows with Biferon-B in $5.0 \mathrm{ml}$ helps reduce the incidence of cows with mastitis by $37.5 \%$. A dosage of 10.0 and $20.0 \mathrm{ml}$ respectively reduces the incidence by $25.0 \%$ and $12.5 \%$
Table 1. Prophylactic efficacy of Biferon-B

\begin{tabular}{|l|c|c|c|c|}
\hline Indicator & $\begin{array}{l}\text { I group } \\
(5.0 \mathrm{ml})\end{array}$ & $\begin{array}{c}\text { II group } \\
(10.0 \mathrm{ml})\end{array}$ & $\begin{array}{c}\text { III group } \\
(20.0 \mathrm{ml})\end{array}$ & $\begin{array}{c}\text { IV group } \\
\text { (negative } \\
\text { control) }\end{array}$ \\
\hline $\begin{array}{l}\text { Number of } \\
\text { animals }\end{array}$ & 16 & 16 & 16 & 16 \\
\hline $\begin{array}{l}\text { Diseased: } \\
\text { subclinical } \\
\text { mastitis } \\
\text { [animals] (\%) } \\
\text { clinically } \\
\text { severe } \\
\text { [animals] (\%) }\end{array}$ & $1(6.25)$ & $2(12.5)$ & $2(12.5)$ & $4(25.0)$ \\
\hline $\begin{array}{l}\text { Prophylactic } \\
\text { efficacy [\%] }\end{array}$ & $37.5 \%$ & $25.0 \%$ & $12.5 \%$ & $4(25.0)$ \\
\hline
\end{tabular}

Thus, the optimal dose of Biferon-B with its intramuscular monthly administration twice a day with an interval of 48 hours is $5.0 \mathrm{ml}$.

The results of clinical studies were confirmed by data on the study of immunological blood counts before and after the use of interferons (Table 2).

Table 2. Indicators of the immunobiochemical status of cows after administration of $5.0 \mathrm{ml}$ of Biferon-B

\begin{tabular}{|c|c|c|}
\hline Indicators & $\begin{array}{c}\text { Before } \\
\text { experiment }\end{array}$ & After experiment \\
\hline Erythrocytes $\left[10^{12} / 1\right]$ & $5.7 \pm 0.2$ & $6.4 \pm 0.3$ \\
\hline Hemoglobin [g/l] & $103.6 \pm 2.7$ & $105.8 \pm 4.5$ \\
\hline Leukocytes $\left[10^{9} / 1\right]$ & $7.6 \pm 0.6$ & $8.4 \pm 0.9$ \\
\hline Stab neutrophils [\%] & $3.4 \pm 0.3$ & $1.4 \pm 0.2$ \\
\hline Segmented neutrophils [\%] & $42.5 \pm 2.7$ & $45.4 \pm 1.4$ \\
\hline Eosinophils [\%] & $5.0 \pm 0.4$ & $4.4 \pm 0.6$ \\
\hline Monocytes [\%] & $2.1 \pm 0.2$ & $3.3 \pm 0.2$ \\
\hline Lymphocytes [\%] & $47.0 \pm 0.6$ & $49.3 \pm 0.7$ \\
\hline Total Jg [g/l] & $26.6 \pm 1.4$ & $30.4 \pm 1.5^{*}$ \\
\hline $\mathrm{CIC}[\mathrm{g} / \mathrm{l}]$ & $0.428 \pm 0.02$ & $0.160 \pm 0.01^{* *}$ \\
\hline SBA [\%] & $51.7 \pm 3.0$ & $63.6 \pm 1.6^{*}$ \\
\hline SLA $[\mu \mathrm{g} / \mathrm{ml}]$ & $0.344 \pm 0.03$ & $0.391 \pm 0.03^{*}$ \\
\hline LPR [\%] & $58.9 \pm 2.1$ & $65.3 \pm 2.2$ \\
\hline PI [cells/active phagocyte] & $3.3 \pm 0.12$ & $3.8 \pm 0.14$ \\
\hline PN [cells/phagocyte] & $5,6 \pm 0.39$ & $6.1 \pm 0.31$ \\
\hline MMP [a.u.] & $1.520 \pm 0.09$ & $1.176 \pm 0.08^{*}$ \\
\hline IEI & $11.0 \pm 0.55$ & $8.9 \pm 0.53^{*}$ \\
\hline $\mathrm{NO}[\mu \mathrm{M} / \mathrm{L}]$ & $105.9 \pm 10.0$ & $57.8 \pm 4.8^{*}$ \\
\hline $\mathrm{MDA}[\mu \mathrm{M} / \mathrm{L}]$ & $4.12 \pm 0.18$ & $2.61 \pm 0.12^{* * *}$ \\
\hline $\mathrm{GPx}[\mu \mathrm{M} / 1 \cdot \mathrm{min}]$ & $14.8 \pm 0.9$ & $19.2 \pm 1.2^{*}$ \\
\hline Catalase $[\mu \mathrm{M} / 1 \cdot \mathrm{min}]$ & $21.9 \pm 1.3$ & $27.8 \pm 1.3^{*}$ \\
\hline
\end{tabular}

It was found that in the blood of cows of animals of the first group (Biferon-B, $5.0 \mathrm{ml}$ each), a $58.8 \%$ decrease in the number of stab neutrophils and $62.6 \%$ in circulating immune complexes $(\mathrm{P}<0.05)$ was noted over the observation period, with a higher content of segmented neutrophils by $6.8 \%$, monocytes by $57.1 \%$, lymphocytes by $4.9 \%$, total immunoglobulins by $14.3 \%$ (P <0.05), bactericidal and lysozyme activity of blood serum by $23.1 \%(\mathrm{P}<0.05)$ and $13.7 \%$, respectively, of the phagocytic activity of neutrophils by $10.9 \%$. The intoxication index lowered by $19.1 \%(\mathrm{P}<0.05)$, the content of average molecular peptides by $22.6 \%$ $(\mathrm{P}<0.05)$, nitric oxide by $45.4 \% \quad(\mathrm{P}<0.05)$, MDA by $36.7 \%(\mathrm{P}<0.001)$. The activity of catalase increased by $26.9 \%(\mathrm{P}<0.05)$, and GPx by $29.7 \%(\mathrm{P}<0.05)$.

An increase in the number of monocytes, an increase in the absorption capacity of neutrophils testifies to the 
positive effect of Biferon-B on the cells causing intensification of phagocytosis. An increase in the content of lysozyme, one of the main factors of antimicrobial protection, indicates a high proliferative activity of the granulocytes, monocytes and macrophages synthesizing it, and indicates an increase in natural nonspecific resistance. The positive effect of Biferon-B on a decrease in antigenic load under the influence of recombinant interferons is evidenced by a decrease in the number of CICs, the antigen-antibody reaction products involved in maintaining homeostasis. The normalization of the lipid peroxidation - antioxidant system is indicated by a decrease in the concentration of malondialdehyde, while increasing the activity of catalase and glutathione peroxidase.

In relation to the animals of the control group, at the end of the experiment, there was a decrease in the number of circulating immune complexes by $65.4 \%$, nitric oxide by $16.1 \%$, medium-molecular peptides by $22.9 \%$, intoxication index by $36.6 \%$, with an increase in the number lymphocytes by $2.5 \%$, the content of total immunoglobulins by $21.5 \%$ of the bactericidal and lysozyme activity of blood serum by $14.8 \%$ and $9.9 \%$, respectively.

Table 3. Indicators of the immunobiochemical status of cows after administration of $10.0 \mathrm{ml}$ of Biferon-B

\begin{tabular}{|c|c|c|}
\hline Indicators & $\begin{array}{c}\text { Before } \\
\text { experiment }\end{array}$ & $\begin{array}{c}\text { After } \\
\text { experiment }\end{array}$ \\
\hline Erythrocytes $\left[10^{12} / 1\right]$ & $5.6 \pm 0.2$ & $6.4 \pm 0.3$ \\
\hline Hemoglobin [g/l] & $100.1 \pm 3.6$ & $102.0 \pm 5.7$ \\
\hline Leukocytes $\left[10^{9} / 1\right]$ & $7.7 \pm 0.7$ & $8.2 \pm 0.6$ \\
\hline Stab neutrophils [\%] & $4.4 \pm 0.8$ & $1.5 \pm 0.6^{* *}$ \\
\hline Segmented neutrophils [\%] & $40.0 \pm 2.5$ & $43.1 \pm 2.1$ \\
\hline Eosinophils [\%] & $4.9 \pm 0.3$ & $3.1 \pm 0.4$ \\
\hline Monocytes [\%] & $3.6 \pm 0.1$ & $3.9 \pm 0.1$ \\
\hline Lymphocytes [\%] & $47.1 \pm 2.7$ & $49.4 \pm 2.3$ \\
\hline Total Jg [g/l] & $25.6 \pm 1.3$ & $28.5 \pm 0.9$ \\
\hline CIC $[\mathrm{g} / \mathrm{l}]$ & $0.518 \pm 0.03$ & $0.201 \pm 0.02^{* * * *}$ \\
\hline SBA [\%] & $57.1 \pm 2.7$ & $65.6 \pm 1.1^{*}$ \\
\hline SLA $[\mu \mathrm{g} / \mathrm{ml}]$ & $0.417 \pm 0.03$ & $0.431 \pm 0.03$ \\
\hline LPR [\%] & $61.2 \pm 3.18$ & $64.6 \pm 3.87$ \\
\hline PI [cells/active phagocyte] & $3.4 \pm 0.27$ & $3.7 \pm 0.14$ \\
\hline PN [cells/phagocyte] & $5.5 \pm 0.25$ & $5.8 \pm 0.22$ \\
\hline MMP [a.u.] & $1.146 \pm 0.06$ & $1.014 \pm 0.09$ \\
\hline IEI & $10.2 \pm 0.08$ & $8.9 \pm 0.79$ \\
\hline $\mathrm{NO}_{\mathrm{x}}[\mu \mathrm{M} / \mathrm{l}]$ & $73.2 \pm 4.2$ & $48.21 \pm 3.7^{*}$ \\
\hline $\mathrm{MDA}[\mu \mathrm{M} / \mathrm{L}]$ & $3.84 \pm 0.12$ & $3.72 \pm 0.08$ \\
\hline $\mathrm{GPx}[\mu \mathrm{M} / 1 \cdot \min ]$ & $15.1 \pm 0.8$ & $17.0 \pm 1.3$ \\
\hline Catalase $\left[\mu \mathrm{M}_{\mathrm{H} 2 \mathrm{O} 2} / \mu \mathrm{min}\right]$ & $22.7 \pm 1.4$ & $24.9 \pm 1.4$ \\
\hline
\end{tabular}

In the blood of cows of the second group (Table 3), a decrease in the number of stab neutrophils by $65.9 \%$ $(\mathrm{P}<0.01)$, the content of circulating immune complexes by $61.2 \%(\mathrm{P}<0.001)$, nitric oxide by $34.2 \%(\mathrm{P}<0.05))$, average molecular peptides by $11.5 \%$, endogenous intoxication index by $12.8 \%$ was noted, with an increase in the number of segmented neutrophils by $7.8 \%$, lymphocytes by $4.9 \%$, total immunoglobulins by $11.3 \%$ $(\mathrm{P}<0.05)$, bactericidal activity of blood serum by $14.9 \%$ $(\mathrm{P}<0.05)$ and SLA by $4.3 \%$. When using bovine recombinant $\alpha$ - and $\gamma$-interferons of $10.0 \mathrm{ml}$, an increase in the phagocytic activity of leukocytes by $5.6 \%$ was established throughout the entire period of the experiment, including a phagocytic index by $8.8 \%$ and a phagocytic number by $5.5 \%$, indicating the activation of cellular component of immune system.

In cows of this group, the functioning of the lipid peroxidation - antioxidant system was normalized, as evidenced by a decrease in the concentration of malondialdehyde during the experiment by $1.1 \%$, with a simultaneous increase in the activity of catalase and glutathione peroxidase by 9.7 and $12.6 \%$, respectively.

In relation to the animals of the control group, at the end of the experiment, there was a decrease in the number of circulating immune complexes by $56.4 \%$, nitric oxide by $30.1 \%$, medium-molecular peptides by $22.9 \%$, intoxication index by $36.6 \%$, with an increase the content of total immunoglobulins by $23.0 \%$, bactericidal and lysozyme activity of blood serum by $18.4 \%$ and $16.3 \%$ and phagocytic activity of neutrophils by $11.9 \%$, respectively.

In cows of the third group (Table 4), there was a decrease in the number of stab neutrophils in the blood by $61.3 \%$, circulating immune complexes by $23.4 \%$, nitric oxide by $24.5 \%$, intoxication index by $17.0 \%$, with an increase in the number of segmented neutrophils by $4.8 \%$, lymphocytes by $12.3 \%$, total immunoglobulins by $5.7 \%$, bactericidal and lysozyme activity of blood serum by $6.4 \%$ and $9.5 \%$, respectively. The indicator of the cellular component of immunity, the phagocytic activity of leukocytes, slightly decreased by $3.9 \%$ in relation to the initial level. The phagocytic number and phagocytic index had a similar tendency.

Table 4. Indicators of the immunobiochemical status of cows after administration of $20.0 \mathrm{ml}$ of Biferon-B

\begin{tabular}{|c|c|c|}
\hline Indicators & $\begin{array}{c}\text { Before } \\
\text { experiment }\end{array}$ & $\begin{array}{c}\text { After } \\
\text { experiment }\end{array}$ \\
\hline Erythrocytes $\left[10^{12} / 1\right]$ & $5.8 \pm 0.2$ & $6.1 \pm 0.3$ \\
\hline Hemoglobin [g/l] & $100.6 \pm 3.2$ & $103.8 \pm 9$ \\
\hline Leukocytes $\left[10^{9} / 1\right]$ & $8.2 \pm 1.1$ & $8.4 \pm 0.6$ \\
\hline Stab neutrophils [\%] & $3.1 \pm 0.6$ & $1.9 \pm 0.4$ \\
\hline Segmented neutrophils [\%] & $39.3 \pm 2.1$ & $41.2 \pm 1.9$ \\
\hline Eosinophils [\%] & $5.4 \pm 0.3$ & $4.0 \pm 0.4$ \\
\hline Monocytes [\%] & $3.6 \pm 0.2$ & $3.8 \pm 0.1$ \\
\hline Lymphocytes [\%] & $48.6 \pm 0.9$ & $49.1 \pm 3.3$ \\
\hline Total Jg [g/l] & $26.4 \pm 1.2$ & $27.9 \pm 1.2$ \\
\hline $\mathrm{CIC}[\mathrm{g} / \mathrm{l}]$ & $0.410 \pm 0.03$ & $0.314 \pm 0.019$ \\
\hline SBA [\%] & $51.8 \pm 3.9$ & $55.1 \pm 5.5$ \\
\hline $\mathrm{SLA}[\mu \mathrm{g} / \mathrm{ml}]$ & $0.327 \pm 0.03$ & $0.358 \pm 0.019$ \\
\hline LPR [\%] & $60.8 \pm 4.23$ & $58.4 \pm 4.22$ \\
\hline PI [cells/active phagocyte] & $3.5 \pm 0.18$ & $3.4 \pm 0.12$ \\
\hline PN [cells/phagocyte] & $5.7 \pm 0.33$ & $5.6 \pm 0.34$ \\
\hline MMP [a.u.] & $1.319 \pm 0.09$ & $1.287 \pm 0.06$ \\
\hline IEI & $13.5 \pm 0.8$ & $11.2 \pm 0.7$ \\
\hline $\mathrm{NO}_{\mathrm{x}}[\mu \mathrm{M} / 1]$ & $81.1 \pm 7.45$ & $61.3 \pm 3.12$ \\
\hline $\mathrm{MDA}[\mu \mathrm{M} / \mathrm{L}]$ & $3.91 \pm 0.15$ & $3.80 \pm 0.08$ \\
\hline $\mathrm{GPx}[\mu \mathrm{M} / 1 \cdot \min ]$ & $14.5 \pm 1.1$ & $14.9 \pm 1.1$ \\
\hline Catalase $\left[\mu \mathrm{M}_{\mathrm{H} 2 \mathrm{O} 2} / \mu \mathrm{min}\right]$ & $23.1 \pm 0.9$ & $25.5 \pm 1.3$ \\
\hline
\end{tabular}

By the end of the experiment, the content of malondialdehyde decreased by $2.8 \%$, while the indices of the enzymatic link of antioxidant protection, on the contrary, increased. Thus, the activity of catalase and glutathione peroxidase increased by $10.4 \%$ and $3.5 \%$, respectively, indicating a decrease in lipid peroxidation processes. 
In relation to the animals of the control group, at the end of the experiment, there was a decrease in the content of nitric oxide by $12.4 \%$, medium molecular peptides by $15.7 \%$, intoxication index by $19.9 \%$, with an increase in the number of lymphocytes by $3.2 \%$, the content of total immunoglobulins by $11.5 \%$.

In the cows of the control group that were not subjected to drug treatment, the content of circulating immune complexes increased by $13.8 \%$, mediummolecular peptides by $10.6 \%$, and the number of monocytes decreased by $12.5 \%$ (Table 5). 5).

Table 5. Indicators of immunobiochemical status of cows in the control group

\begin{tabular}{|c|c|c|}
\hline Indicators & $\begin{array}{c}\text { Before } \\
\text { experiment }\end{array}$ & After experiment \\
\hline 1 & 2 & 3 \\
\hline Erythrocytes $\left[10^{12} / 1\right]$ & $5.5 \pm 0.3$ & $5.6 \pm 0.3$ \\
\hline Hemoglobin $[\mathrm{g} / 1]$ & $100.4 \pm 2.1$ & $104.4 \pm 2.3$ \\
\hline Leukocytes $\left[10^{9} / 1\right]$ & $7.7 \pm 0.4$ & $7.8 \pm 0.4$ \\
\hline Stab neutrophils [\%] & $2.8 \pm 0.2$ & $3.1 \pm 0.2$ \\
\hline $\begin{array}{l}\text { Segmented } \\
\text { neutrophils [\%] }\end{array}$ & $37.4 \pm 1.8$ & $35.9 \pm 2.3$ \\
\hline Eosinophils [\%] & $6.6 \pm 0.3$ & $7.7 \pm 0.5$ \\
\hline Monocytes [\%] & $4.0 \pm 0.3$ & $3.5 \pm 0.2$ \\
\hline 1 & 2 & 3 \\
\hline Lymphocytes [\%] & $49.2 \pm 0.9$ & $49.8 \pm 2.9$ \\
\hline Total Jg [g/l] & $24.9 \pm 1.15$ & $25.0 \pm 0.84$ \\
\hline $\mathrm{CIC}[\mathrm{g} / \mathrm{l}]$ & $0.406 \pm 0.04$ & $0.462 \pm 0.029$ \\
\hline SBA [\%] & $56.8 \pm 1.9$ & $55.4 \pm 2.4$ \\
\hline SLA $[\mu \mathrm{g} / \mathrm{ml}]$ & $0.196 \pm 0.02$ & $0.252 \pm 0.037$ \\
\hline LPR [\%] & $60.3 \pm 4.12$ & $56.9 \pm 4.11$ \\
\hline $\begin{array}{l}\text { PN [cells/ } \\
\text { phagocyte] }\end{array}$ & $5.6 \pm 021$ & $5.7 \pm 0.25$ \\
\hline MMP [a.u.] & $1,380 \pm 0.13$ & $1.526 \pm 0.06$ \\
\hline IEI & $15.1 \pm 0.4$ & $14.1 \pm 0.7$ \\
\hline $\mathrm{NO}_{\mathrm{x}}[\mu \mathrm{M} / 1]$ & $76.9 \pm 6.8$ & $78.9 \pm 4.1$ \\
\hline $\mathrm{MDA}[\mu \mathrm{M} / \mathrm{L}]$ & $3.87 \pm 0.12$ & $3.86 \pm 0.11$ \\
\hline $\mathrm{GPx}[\mu \mathrm{M} / 1 \cdot \mathrm{min}]$ & $14.0 \pm 1.1$ & $14.5 \pm 1.1$ \\
\hline $\begin{array}{l}\text { Catalase } \\
{\left[\mu \mathrm{M}_{\mathrm{H} 2 \mathrm{O} 2} / \mu \mathrm{min}\right]}\end{array}$ & $22.5 \pm 1.2$ & $22.1 \pm 1.2$ \\
\hline
\end{tabular}

The use of Biferon-B, increasing the immune status, had a positive effect on the clinical condition of lactating cows, contributing to the normalization of the immune status of the mammary gland. During the study period, in animals of the first experimental group, a decrease in the content of circulating immune complexes by $51.3 \%$ $(\mathrm{P}<0.05)$, total immunoglobulins by $21.4 \%(\mathrm{P}<0.05)$, and lysozyme by $56.1 \%(\mathrm{P}<0.01)$ was observed in milk, while the content of somatic cells was not significantly changed (Table 6).

Animals of the second experimental group $(10.0 \mathrm{ml}$ of Biferon-B for each) showed a lower content of circulating immune complexes by $25.9 \%(\mathrm{P}<0.05)$, total immunoglobulins by $17.3 \%$, lysozyme by $44.0 \%$, somatic cell content increased 2.04 times $(\mathrm{P}<0.05)$.

In milk of cows of the third experimental group (20.0 ml Biferon-B for each), a lower content of circulating immune complexes in milk was found to be $32.6 \% \quad(\mathrm{P}<0.05)$, total immunoglobulins by $4.3 \%$, lysozyme content by $31.1 \%$, however, the somatic cell content increased by 2.01 times.

Animals of the control group showed an increase in lysozyme level by $54.7 \%$, circulating immune complexes by $16.4 \%$, total immunoglobulins by $93.2 \%$, and somatic cells by 2.8 times.

Table 6. Indicators of the secretion of mammary gland after application of Biferon-B

\begin{tabular}{|c|c|c|}
\hline Indicators & $\begin{array}{c}\text { Before } \\
\text { experiment }\end{array}$ & After experiment \\
\hline \multicolumn{3}{|c|}{$5.0 \mathrm{ml}$} \\
\hline Lysozyme [mg/ml] & $0.323 \pm 0.020$ & $0.142 \pm 0.019^{* *}$ \\
\hline $\mathrm{CIC}[\mathrm{g} / \mathrm{l}]$ & $0.271 \pm 0.04$ & $0.132 \pm 0.008^{*}$ \\
\hline Total Ig [g/l] & $2.2 \pm 0.1$ & $1.7 \pm 0.1^{*}$ \\
\hline $\mathrm{SC}\left[10^{3} / \mathrm{ml}\right]$ & $73.8 \pm 13.8$ & $100.6 \pm 21.6$ \\
\hline \multicolumn{3}{|c|}{$10.0 \mathrm{ml}$} \\
\hline Lysozyme $[\mathrm{mg} / \mathrm{ml}]$ & $0.293 \pm 0.03$ & $0.164 \pm 0.025$ \\
\hline $\mathrm{CIC}[\mathrm{g} / \mathrm{l}]$ & $0.205 \pm 0.04$ & $0.152 \pm 0.017^{*}$ \\
\hline Total Ig [g/l] & $2.3 \pm 0.08$ & $1.9 \pm 0.08$ \\
\hline $\mathrm{SC}\left[10^{3} / \mathrm{ml}\right]$ & $93.2 \pm 20.9$ & $189.8 \pm 19.4^{*}$ \\
\hline \multicolumn{3}{|c|}{$20.0 \mathrm{ml}$} \\
\hline Lysozyme [mg/ml] & $0.273 \pm 0.02$ & $0.188 \pm 0.031$ \\
\hline $\mathrm{CIC}[\mathrm{g} / \mathrm{l}]$ & $0.258 \pm 0.04$ & $0.174 \pm 0.001^{*}$ \\
\hline Total Ig [g/l] & $2.3 \pm 0.1$ & $2.2 \pm 0.2$ \\
\hline $\mathrm{SC}\left[10^{3} / \mathrm{ml}\right]$ & $119.2 \pm 30.8$ & $240.0 \pm 41.9$ \\
\hline \multicolumn{3}{|c|}{ negative control } \\
\hline Lysozyme [mg/ml] & $0.223 \pm 0.02$ & $0.345 \pm 0.019$ \\
\hline $\mathrm{CIC}[\mathrm{g} / \mathrm{l}]$ & $0.213 \pm 0.02$ & $0.248 \pm 0.009$ \\
\hline Total Ig [g/l] & $1.77 \pm 0.13$ & $3.42 \pm 0.34$ \\
\hline $\mathrm{SC}\left[10^{3} / \mathrm{ml}\right]$ & $101.4 \pm 61.5$ & $283.2 \pm 22.8^{*}$ \\
\hline
\end{tabular}

Bacteriological studies of the milk of animal experimental groups found that over the period of the experiment there was a decrease in the bacterization of milk with microflora when using $5.0 \mathrm{ml}$ of Biferon-B by 92.7 times, for $10.0 \mathrm{ml}$ by 141.8 times and for $20.0 \mathrm{ml}$ by 22.2 times (Table 7). Moreover, the mammary gland infection rate in animals of the first group was $40.0 \%$, $80.0 \%$, in the second group, $80.0 \%$, in the third one and $100.0 \%$ in the fourth.

Table 7. Milk bacterization [thousand CFU/ml]

\begin{tabular}{|l|c|c|}
\hline \multicolumn{1}{|c|}{ Preparation } & $\begin{array}{c}\text { Before } \\
\text { experiment }\end{array}$ & $\begin{array}{c}\text { After } \\
\text { experiment }\end{array}$ \\
\hline \multicolumn{3}{|c|}{ Bacterization [CFU/ml] } \\
\hline $5.0 \mathrm{ml}$ of Biferon-B & $3.12 \pm 0.11$ & $0.03 \pm 0.01$ \\
\hline $10.0 \mathrm{ml}$ of Biferon-B & $3.83 \pm 0.21$ & $27.0 \pm 13.7$ \\
\hline $20.0 \mathrm{ml}$ of Biferon-B & $3.76 \pm 0.21$ & $169.4 \pm 95.7$ \\
\hline Negative control & $1.41 \pm 0.68$ & $874.0 \pm 255.5$ \\
\hline \multicolumn{2}{|c|}{ of infected } \\
\hline $5.0 \mathrm{ml}$ of Biferon-B & 100.0 & 40.0 \\
\hline $10.0 \mathrm{ml}$ of Biferon-B & 100.0 & 80.0 \\
\hline $20.0 \mathrm{ml}$ of Biferon-B & 100.0 & 80.0 \\
\hline Negative control & 100.0 & 100.0 \\
\hline
\end{tabular}

Therefore, the monthly use of Biferon-B in a dose of 5-10-20 $\mathrm{ml}$ has a positive effect on the secretion of the mammary gland, providing a reduction in microbial contamination of milk by $20-140$ times, the number of animals with infected mammary gland by $20-60 \%$, optimizes the indicators of protection of the mammary gland (lysozyme, general immunoglobulins, CIC). The resulting effect may be due to the fact that Biferon-B, which has an immunocorrective effect, enhances the activity of phagocytosis and contributes to a more effective elimination of microflora from the mammary gland. 


\section{Conclusion}

Thus, the positive effect of the drug on the immune status of lactating cows is due to the presence of recombinant proteins in its composition, $\alpha$-interferon increases the activity of natural killers, T-helpers, phagocytosis, the intensity of differentiation of Blymphocytes, and also accelerates elimination of circulating immune complexes $[17,18]$.

The stimulating effect of $\gamma$-interferon is associated with the activation of macrophage phagocytic function, the production of reactive oxygen and nitrogen species, prostaglandins; in addition, it activates $\mathrm{T}$-helpers and $\mathrm{T}$ cytotoxic lymphocytes, stimulates the differentiation of B-cells for the production of G-immunoglobulins and the migration of lymphocytes in tissue, thereby enhancing the immune cell response $[19,20]$.

The studies made it possible to develop a method for the prevention of mastitis in lactating cows using Biferon-B, to show its role in optimizing the immune status of animals, reducing the number of infected animals and improving the quality of milk produced.

\section{References}

1. M.V. Ryaposova, M.N. Tarasenko, Quarterly information and analytical magazine. Regulatory issues in veterinary medicine 3,154-157 (St. Petersburg, 2014)

2. T. Halasa, M. Nielen, A.P.W. De Roos et al., J. of Dairy Sci. 92(2), 599-606 (2009)

3. V.I. Slobodyanik, Vestnik of Veterinary Med. 1-2, 135-144 (2007)

4. I.G. Konopeltsev, Russ. Veter. J. 5, 33-35 (2007)

5. O.A. Artemyeva, D.A. Nikanova, E.N. Kotikovskaya et al., Agricultural Biology 51(6), 867-874 (2016)

6. F. Gomes, M. Henriques, Current Microbiology 72(4), 377-382 (2016)
7. G.M. Boxx, G. Cheng, Cell Host \& Microbe 19(6), 760-769 (2016)

8. E.M. Eshleman, L.L. Lenz, Front Immunol. 5, 431 (2014)

9. H.M. Johnson, Front Immunol. 5, 667 (2015)

10. S. Baron, D. Weigent, G.J. Stanton, J. Peterson, Antiviral Res. 5 (Suppl. 1), 173-183 (1985)

11. A.N. Vasiliev, P.G. Deryabin, G.A. Galegov, Antibiotics and Chemotherapy 56(9-10), 27-32 (2011)

12. A. Razaghi, L. Owens, K.J. Heimann, Biotechnol. 240, 48-60 (2016)

13. O.A. Kozlova, G.F. Medvedev, M.I. Potapovich, V.A. Prokulevich, In: Actual problems of the intensive development of animal husbandry, Gorki, 21, part 2, 3-10, (2018)

14. S.V. Shabunin, N.T. Klimov, V.I. Zimnikov et al., Veter. Med. 3, 39-42 (2018)

15. M.I. Retsky, A.G. Shakhov, V.I. Shushlebin et al., Guidelines for the diagnosis, therapy and prevention of metabolic disorders in productive animals. Methodological recommendations (Voronezh, 2005)

16. A.G. Shakhov, Yu.N. Masyanov, M.I. Retskiy et al., Methodological recommendations for the assessment and correction of the immune status of animals (Voronezh, 2005)

17. L. Rönnblom, Clin. Exp. Rheumatol. 34 (4 Supple. 98), 21-24 (2016)

18. J.M. González-Navajas, J. Lee, M. David, E. Raz, Nature Reviews Immunology 12, 125-135 (2012)

19. X. Su, Y. Yu, Y. Zhong, E.G. Giannopoulou et al., Nature Immunology 16, 838-849 (2015)

20. S.V. Shabunin, A.G. Shakhov, G.A. Vostroilova et al., Agricultural Biology 53(4), 851-859 (2018) 